\title{
HAEMATOLOGY OF THE FRESHWATER FISH BARILIS BOLA (HAM.) IN RELATION TO ITS HABITAT ECOLOGY IN THE TRIBUTARIES OF RIVER SONG
}

\author{
Neelam Nautiyal, J.V.S. Rauthan, and Shepali Chalotra \\ Department of Zoology, D.A.V (P.G.) College, Dehradun-248001, Uttarakhand
}

Corresponding Author Email Id: neelamnautiyalrudra123@gmail.com

Received: 02.12.2019; Revised: 12.12.2019; Accepted: 19.12.2019

CSociety for Himalayan Action Research and Development

\begin{abstract}
The present investigation was carried out to analyse the effect of water quality on haematological parameters in the hill trout Barilius bola (Ham.) using the standard methods. The study of fish blood parameters is important for determining factors related to their physiological capacity. Haematological and same biochemical contents of the blood in relation to physico-chemical characteristics of the water have been studied in the fresh fish. The results indicated that normal values have been found in comparison to the studies carried out in other fish. Hence the fish Barilius bola in having favorable environmental temperature, $\mathrm{pH}$ and dissolved oxygen required for the fish to survive and regulate breeding activities.
\end{abstract}

Keywords: Haematology, Barilius bola

\section{Introduction}

Fish haematology is an important aspect to find out its physiological strength. The physiological parameters such as RBC, WBC, haemoglobin content and other related parameters are used to assess the health status and oxygen carrying capacity of the blood. The release of chemicals into the aquatic environment result in significant changes which may threaten functional attributes, the integrity and existence of aquatic organisms, especially fish. Recently haematology parameters have been used as bio-makers in measuring the effects of pollutant in fish. Haematology is used as an index of fish health in various fish species to detect physiological changes during different stress conditions like exposure to pollutants, diseases, metals hypoxia etc. To use these blood parameters with a diagnostic purpose, it is necessary to analyze healthy fish in the best ambient conditions to establish the reference indices for the species object of study as well.

\section{Materials and Methods}

Adult Barilius bola (20-25 cm in length and 200$350 \mathrm{gm}$ in weight) were caught from tributaries of River Song in Nepali farm and Raiwala, Dehradun during February 2018 to January 2019. A total 10 fish were collected using cast net. Immediately after capturing $2 \mathrm{ml}$ blood was taken to cardiac puncture using heparanized syringe. Haematological analyses, TEC and TLC, were made using an improved Neubauer haematocytometer. $\mathrm{Hb}$ was estimated by Sahli's haematin method. PCV was estimated by Wintrobe tube method $\mathrm{MCV}\left(\mu \mathrm{m}^{3}\right), \mathrm{MCH}(\mathrm{pg})$ and $\mathrm{MCHC}(\%)$ were calculated using following formulae:

$$
\begin{array}{lll}
\mathrm{MCV} & = & \mathrm{PCV} \times 10 / \mathrm{RBC} \text { count } \\
\mathrm{MCH} & = & \mathrm{Hb} / \mathrm{RBC} \text { count } \\
\mathrm{MCHC} & = & \mathrm{Hb} \times 100 / \mathrm{PCV}
\end{array}
$$

Routine haematological methods were used based on Blaxhall, and Diosley (1973) and Dacie and Lewis (2001). The water samples were collected 
from Song River simultaneously during the fish collection and brought to the laboratory for determining dissolved oxygen and the other parameters (APHA 1998). Temperature of the water was recorded at the site of collection by digital thermometer.

\section{Observation}

Haematological parameters of the fish Barilius bola were studied in relation to physico-chemical characteristics of water to find out the favourable conditions for survival and physiological activity.
The haematological parameters and physico chemical properties interaction of fresh water fish Barilius bola from Song River in Doon Valley is presented in Table 1. It shows that the water temperature was observed minimum in winter $\left(20^{\circ} \mathrm{C}\right)$ and maximum in summer $\left(30.1^{\circ} \mathrm{C}\right)$. Value of $\mathrm{pH}$ was minimum in monsoon (7.11) and maximum in summer (8.2). Dissolved oxygen was high in summer (12.2 mg. $\left.\mathrm{l}^{-1}\right)$ and lowest in rainy season $\left(7.2^{-1} \mathrm{mg} \cdot \mathrm{l}^{-1}\right)$. Seasonal changes in haematological parameters are shown in Table 1

Table 1: Haematological and habitat characteristic parameters of the fish B. Bola from Song river during different seasons.

\begin{tabular}{|l|l|l|l|}
\hline \multicolumn{1}{|c|}{ Parameters } & \multicolumn{1}{c|}{ Winter Season } & \multicolumn{1}{c|}{ Summer Season } & \multicolumn{1}{c|}{ Rainy Season } \\
\hline Water temperature $\left({ }^{0} \mathrm{C}\right)$ & 20.00 & 30.1 & 26.0 \\
\hline Dissolved oxygen $\left(\mathrm{mg} .1^{-1}\right)$. & 10.0 & 12.20 & 7.2 \\
\hline $\mathrm{pH}$ & 7.25 & 8.2 & 7.11 \\
\hline $\mathrm{RBC}\left(\mathrm{x} 10^{6} / \mathrm{mm}^{3}\right)$ & $1.20 \pm 0.44$ & $1.44 \pm 0.16$ & $1.36 \pm 0.14$ \\
\hline $\mathrm{WBC}\left(\mathrm{x} 10^{6} / \mathrm{mm}^{3}\right)$ & $3.90 \pm 0.66$ & $3.88 \pm 0.19$ & $3.11 \pm 0.40$ \\
\hline $\mathrm{Hb}(\mathrm{gm} \mathrm{\% )}$ & 7.20 & 8.20 & 8.80 \\
\hline PCV $(\%)$ & 40.25 & 39.20 & 36.10 \\
\hline $\mathrm{MCV}\left(\mu \mathrm{m}^{3}\right)$ & $218.6 \pm 40.2$ & $210.5 \pm 27.2$ & $217.10 \pm 36.2$ \\
\hline MCH $(\mathrm{pg})$ & $38.6 \pm 8.2$ & $38.2 \pm 7.2$ & $44.2 \pm 10.6$ \\
\hline MCHC $(\%)$ & $32.2 \pm 1.31$ & $34.2 \pm 1.22$ & $30.19 \pm 1.66$ \\
\hline Glucose $(\mathrm{mg} / 100 \mathrm{ml})$ & $50.90 \pm 6.60$ & $44.20 \pm 7.0$ & $50.10 \pm 1.69$ \\
\hline Protein $(\mathrm{mg} / 100 \mathrm{ml})$ & $5.50 \pm 0.60$ & $6.60 \pm 0.88$ & $5.0 \pm 0.77$ \\
\hline Urea $(\mathrm{mg} / 100 \mathrm{ml})$ & $26.0 \pm 2.15$ & $28.2 \pm 2.78$ & $30.2 \pm 2.59$ \\
\hline Sodium $(\mathrm{mg} / 100 \mathrm{ml})$ & $80.40 \pm 10.20$ & $79.20 \pm 11.21$ & $78.10 \pm 9.92$ \\
\hline Potassium $(\mathrm{mg} / 100 \mathrm{ml})$ & $13.98 \pm 1.41$ & $12.00 \pm 1.50$ & $10.40 \pm 1.63$ \\
\hline Calcium $(\mathrm{mg} / 100 \mathrm{ml})$ & $9.25 \pm 0.60$ & $10.20 \pm 0.40$ & $8.20 \pm 0.30$ \\
\hline Phosphorous $(\mathrm{mg} / 100 \mathrm{ml})$ & $0.096 \pm 0.001$ & $0.081 \pm 0.002$ & $0.059 \pm 0.001$ \\
\hline
\end{tabular}

\section{Discussion}

Haematological and bio-chemical assessment of peripheral blood is important in evaluating the health of many organisms, including fish. Changes in the proportion of blood cell types are important diagnostic indicators, reflecting diseases and exposure to toxicant. Determination of erythrocyte numbers can indicate the existence of anaemia or stress polycythemia, whereas leucocytosis accounts for infection. Environmental factors such as $\mathrm{pH}$, alkalinity, dissolved oxygen, turbidity, temperature and conductivity influence the rate of reaction of pollutants entering the water or lethal effects on the aquatic organisms (Fagbeno 2002). Impact of petrochemical effluent on haematological parameters in the freshwater fish Labeo rohita has been studied by Kumar et.al. (2019). Water temperature affects all aspects of 
metabolism rate. Increase in alkalinity, acidity and $\mathrm{pH}$ determine fish health and the well being of fish (Jimena et.al. 2005). The blood parameters of the fish Barilius bola in the present study indicates that the values were found to be normal.. The morphological variation in blood cells is also studied by Kalashnikova (1976). The aquatic body also provides proper conditions for survival and breeding activity of fish. The normal ranges of haematological indices has also been studies in the cold water fishes (Joshi 2000) who opined that the haematology is a key parameters to point out differences between population and different environmental conditions and it could be used as bio-markers in future works.

The Packed Cell Volume (PCV) measurements of Red Blood Cells in whole blood while haemoglobin within those erythrocytes is the main transport mechanism for oxygen and carbon-dioxide. The decrease in the haemoglobin and PCV may be because of less number of RBC. In present investigation on the fish Barilius bola collected from Song River, it was obserced to have normal levels of all the blood parameters studied and this may be due to proper amount of $\mathrm{CO}_{2}$ and normal temperature and food availability. The other indices which are commonly used are $\mathrm{MCV}$, $\mathrm{MCH}$ and $\mathrm{MCHC}$ are also found to be normal of RBC count. The glucose concentration depends on the mode of fish life and particularly on its locomotive capacity (Clarke 1998). The glucose levels found in the fish Barilius bola in the present study is normal since the fish is omnivorous and is often exposed to natural food with good amount of carbohydrates. The protein levels were found to be lower. Electrolyte sodium, potassium and calcium level indicates the operation of a variety of homeoestatic mechanism in the body (Clark 1998). Sodium and Potassium play an important role in osmoregulation and homeostatic.

\section{Acknowledgement}

The authors wish to express their sincere thanks to Dr. A. K. Saxena, Principal, D.A.V. (P.G.) College, Dehradun and Dr. Shashi Kiran Solanki, Head, Department of Zoology, D.A.V. (P.G.)
College, Dehradun for providing laboratory facility and valuable suggestions.

\section{References}

APHA (1998) Standard methods for examination of water and waste water. American public health association, 1015 fifteenth St, NW Washington. 15:1- 1134.

Blaxhall, P.C. and Diosley, K.W. (1973). Routine haematological methods for use with blood. Journal of fish Biology 5 : 771-781.

Clark, F. (1998). A review of the scientific justification for maintaining the cetaceans in captivity. A report for the Whale and Dolphin conservation society.

Dacie, J.V. and Lewis, S. M. (2001). Practical haematology $\quad\left(9^{\text {th }} \quad\right.$ Edition $) \quad$ Churchil Livinqstone, London.

Fagbenvo, O.A. (2002). Tilapia : Fish for though, $32^{\text {nd }}$ inaugural lecture, Federal University of Technology, Akure, Nigeria : 77.

Jimena, C., Daniel, A.W., Andres, C.H. and Maria de los, A.B. (2005). Haematological parameters in a neotropical fish Corydoras paleatus captured from pristine and polluted water. Hydorbiologia, 537 : 25-33.

Joshi B.D. (2000). Some aspects of haematology of cold water fish. Cold water aquaculture and fisheries(Eds HR Singh and WS Lakra. Narendra publishing house Delhi.

Kalashnikova, Z.M. (1976). On the classification of morphological elements in the blood fish. $J$. Ichthy. 3(16) : 459-472.

Kumar, M.M., Kumari, S.B., Gopinathan, S., Sujila, J. and Drishja. M.K. (2019). Impact of petrochemical effluent on haematological parameters in the freshwater fish Labeo rohita. Int. J. Pharma. Sci. Res. 10(7) : 33003304. 